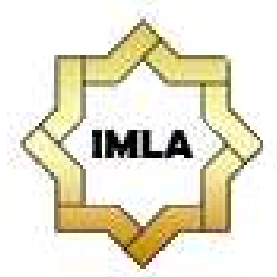

Al-Ta'rib

Jurnal Ilmiah Program Studi Pendidikan Bahasa Arab

IAIN Palangka Raya

Vol. 9, No. 1, June 2021, 1-12

p-ISSN 2354-5887 | e-ISSN 2655-5867

DOI: https://doi.org/10.23971/altarib.v9i1.2530

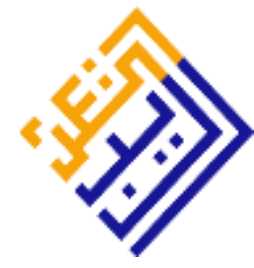

\title{
USING BLOOM'S TAXONOMY IN ARABIC LEARNING MEDIA TO ELEVATE STUDENT'S WRITING IN COVID-19 SITUATION
}

\author{
Zainul Arifin', Suci Ramadhanti Febriani'2, Anasruddin ${ }^{3}$ \\ ${ }^{1}$ Universitas Islam Negeri Imam Bonjol, Padang, Indonesia \\ ${ }^{2}$ Universitas Islam Negeri Maulana Malik Ibrahim Malang, Indonesia \\ 3Institut Qur'an Sulaimaniyah, Turkey \\ E-mail: Zainularifin@uinib.ac.id
}

\begin{abstract}
Learning Arabic writing skills in the Pandemic Era is confronted with complex problems. One of complex problems is the minimal interaction of the limitations in learning process that has an impact on students' learning outcomes. This STUDY aims to explore various Arabic learning media to support learners' writing skills that can be implemented during the COVID-19 situation. The research used a qualitative approach with the case study design. The informants of the study are those who write using online-based writing learning media. The data were collected through observations, and document The findings showed that learning Arabic media based on developing taxonomy can be divided into five basic classifications according to the evolving taxonomy; media understanding stage; YouTube, Facebook, Google search, Twitter, Media application stage: Quick Voice, Animation Creation, Google Doc, media analysis; Mind map, Numbers page, evaluation media; Edmodo, Skype, Google search, Whatsapp, creative media; WordPress, iMovie, YouTube, Creative Books, Instagram. The findings of this study indicated that the process of using online media is an effort to improve creative and critical thinking processes in improving learners' Arabic writing skills. This study examines research to test each of the media used during the COVID-19 situation.
\end{abstract}

Keywords: Arabic Learning; Bloom Taxonomy; Critical Thinking; Media; Writing

\section{Abstrak}

Pembelajaran keterampilan menulis di Era Pandemi mengalami problematika yang kompleks. di antara problematika itu adalah keterbatasan interaksi proses pembelajaran berdampak pada hasil belajar siswa yang tidak maksimal. Hal itu mendorong penelitian ini untuk mengeksplorasi ragam media pembelajaran bahasa Arab untuk mendukung keterampilan menulis siswa sebagai referensi yang dapat diimplementasikan dalam pembelajaran di Era COVID-19. Penelitian ini menggunakan pendekatan kualitatif dengan metode studi kasus. Informan penelitian ini adalah orang yang melaksanakan aktivitas pembelajaran menulis dengan menggunakan media berbasis online. Data diperoleh melalui tehnik observasi, wawancara dan dokumentasi. Sedangkan teknik analisis yang digunakan adalah teknik triangulasi data. Penelitian ini menunjukkan bahwa media 
pembelajaran bahasa Arab berbasis taksonomi bloom dapat dibedakan menjadi lima klasifikasi mendasar sesuai taksonomi bloom; media tahap memahami; YouTube, Facebook, Gooogle search, Twitter, media tahap mengaplikasikan: Quick Voice, Animation Creation, Google Doc, media menganalisis; Mind maping, Numbers Pages, media evaluasi; Edmodoo, Skype, Google search, WhatsApp, 5) media berkreasi; Wordpress, iMovie, YouTube, Creative Book, Instagram. Temuan penelitian ini menunjukkan bahwa proses penggunaan media secara online merupakan salah satu upaya peningkatan proses berpikir kreatif dan kritis dalam meningkatkan keterampilan menulis berbahasa Arab siswa. Penelitian ini merekomendasikan penelitian lanjutan untuk menguji efektivitas masing-masing media yang digunakan pada masa COVID-19.

Kata Kunci: Berpikir Kritis; Media; Menulis; Pembelajaran bahasa Arab; Taxonomi Bloom

\section{Introduction}

Arabic learning during the Corona Virus Pandemic COVID -19 uses a variety of approaches. This is caused by a shift in the paradigm of face-to-face learning to online-based learning (Abidah et al., 2020; Chang \& Fang, 2020). As the report says that Arabic learning can switch to a combination system, online and offline learning (Bahasoan et al., 2020; Febriani et al., 2020). This requires teachers to increase their creativity in designing media following the needs of the times. Transition in the learning process during the COVID-19 pandemic also provides opportunities and challenges for teachers and students (Dhawan, 2020).

The primary challenge experienced by the Arabic language learning system is the use of technology in the process of planning, implementing, and evaluating (Freeman et al., 2016). On that basis, learning is no longer teacher-centered but maximizes student competence and manages the learning process in a more creative and critical direction. These two points are the essential skills that

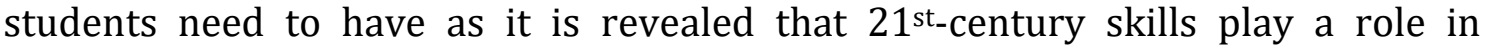
preparing superior resources (Halverson, 2018; Musa et al., 2012).

Previous research has explained that the direction of Arabic learning is based on Higher Order Thinking Skills. Still, it is necessary to improve the quality and quantity of writing skills (Febriani, 2020). Also, research reveals that technology can positively impact productive language skills for speaking and writing skills (Hamat \& Hassan, 2019). It is also in line with the description that each language skill requires habituation even in the online-based learning process (Nassiri et al., 2018).

The research about HOTS-based learning media, MOTS (Middle Order Thinking Skills), or LOTS (Lower Order Thinking Skills) was obtained by identifying indicators of critical thinking skills. As stated, the demand for these skills becomes the basis for forming students' mindset in constructing and solving complex projects given by the teacher. On that basis, the indicators can be seen through the bloom taxonomy.

Bloom's Taxonomy is considered a primary tool for teachers and instructional designers as they provide the main guidelines to follow the educational planning procedures (Rahman \& Manaf, 2017). Bloom reveals that education's primary goals are inseparable from three important domains; 
cognitive, affective, and psychomotor aspects are supporting sustainable learning goals (Zamzami, 2017). Bloom's taxonomy describes the level of skill indicators, from the stage of knowing, describing, analyzing, evaluating, creating, and critical thinking (Pentury \& Anggraeni, 2019). It is known that the level of critical thinking through several stages, so the students can create ideas independently (Aljojo et al., 2019). This can be used as a benchmark in using media that fall into the HOTS, MOTS, or LOTS categories (Teimourtash \& Moghaddam, 2017).

Through several studies have been done as the grouping of each media has not been described constructively. Its have revealed that video conference, zoom, google a classroom is still an option for online learning (Tai et al., 2020). Also, the dissemination of learning media during the COVID-19 pandemic is still a dilemma for teachers to determine each medium's effectiveness (Wargadinata et al., 2020). Related to this fact, various considerations in deciding the press are also urgent (Xuan, 2017), such as using social media for learning also increase the ability of language competencies (Khatri et al., 2020; Rachmijati et al., 2019; Rahayu \& Putri, 2019); (Khatri et al., 2020) and increasing the student's vocabulary (Arndt \& Woore, 2018). But, the challenges in using the media online are still the facts that supporting facilities (Mbodj, 2020). This shows that there is still a need for fundamental research related to media online for increasing writing skills.

Based on previous research descriptions that have discussed the topic of bloom taxonomy, it is still needed to determine the level of media in the HOTS, MOTS, or LOTS categories. This will be constructed in this study to choose media that is suitable for the material teaching. For this reason, this study aims to investigate writing learning media during the COVID-19 emergency into the HOTS, MOTS, or LOTS categories.

\section{Method}

This study used a qualitative research design with a case study method design. Qualitative research aims to see the field phenomena that occur and be described through descriptive analysis through words. Meanwhile, the case study method was chosen to see the facts in a holistic manner (Yin, 2003). Data taken includes interviews with students about implementation media for writing skills in learning online, documentation about the evaluation of writing, and observation about the process in a learning system. 
Figure 1.

Data analysis technique

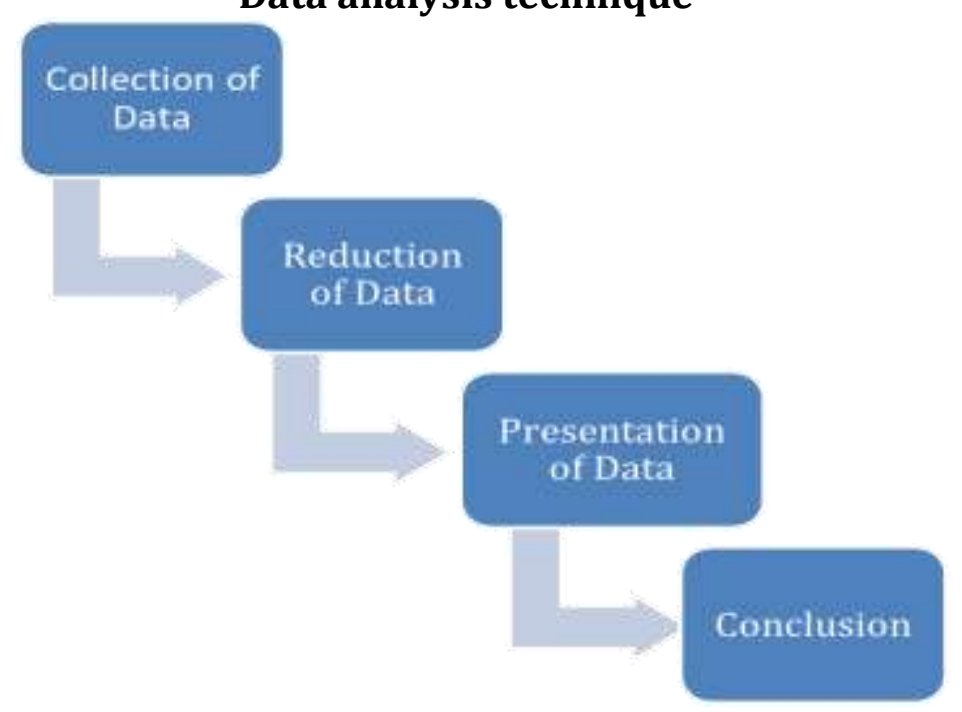

As the steps in Figure 1 in analyzing data are divided into four stages: data collection, reduction, data presentation, and conclusion. This technique adopts data triangulation analysis techniques as the author interviews Arabic language lecturers regarding the development of HOTS, MOTS, and LOTS-based writing media.

Researchers observed learning to write and retrieve data through writing learning planning based on the Learning Implementation Plan. On that basis, this research process uses primary and secondary data sources. Direct data comes from data related to taxonomy bloom-based writing learning and secondary data in the form of written documents that support the strengthening of this research argument.

\section{Result and Discussion}

The process of learning writing skills provides innovations in improving students' abilities. This is seen based on the learning objectives to be achieved. As the competency classification based on HOTS, MOTS, and LOTS can be seen in the following table.

Table 1.

Classification Media based on Taxonomy Blooms

\begin{tabular}{cccc}
\hline Competences & Skills & Writing Skills & Activity \\
\hline $\begin{array}{c}\text { Remembering } \\
\text { Knowledge }\end{array}$ & $\begin{array}{c}\text { Remember Visual } \\
\text { Images }\end{array}$ & Word Phrase & Inspirational Day \\
Understanding & Understanding & Using Mubtada, & Special Visual \\
& Information & Khobar, etc & Merchandising \\
Applying & Using Information & $\begin{array}{c}\text { Identifies detail } \\
\text { synonym/ }\end{array}$ & $\begin{array}{c}\text { Social Media day } \\
\text { andor }\end{array}$ \\
& & antonym &
\end{tabular}




\begin{tabular}{cccc} 
Analyzing & Analyze the Pattern & $\begin{array}{c}\text { Checking or peer } \\
\text { review }\end{array}$ & $\begin{array}{c}\text { Transformation } \\
\text { Momentum }\end{array}$ \\
$\begin{array}{c}\text { Evaluating } \\
\text { Creating }\end{array}$ & $\begin{array}{c}\text { Comparing Ideas } \\
\text { Create the Images }\end{array}$ & $\begin{array}{c}\text { Kind sentences } \\
\text { Creates idea in an } \\
\text { online system }\end{array}$ & $\begin{array}{c}\text { Let's Evaluate it } \\
\text { Create it }\end{array}$ \\
\hline
\end{tabular}

Based on Table 1, it is known that the classification of writing competencies can be made systematically based on the themes that will be given to students. This can be maximized using online social media. The use of Bloom's Taxonomybased media also makes it easier for instructors to determine the appropriate media in learning writing skills (Pentury \& Anggraeni, 2019). As the choice of learning media can be constructed through the following picture.

\section{Figure 3. \\ Classification of Writing Media Based on Bloom's Taxonomy}

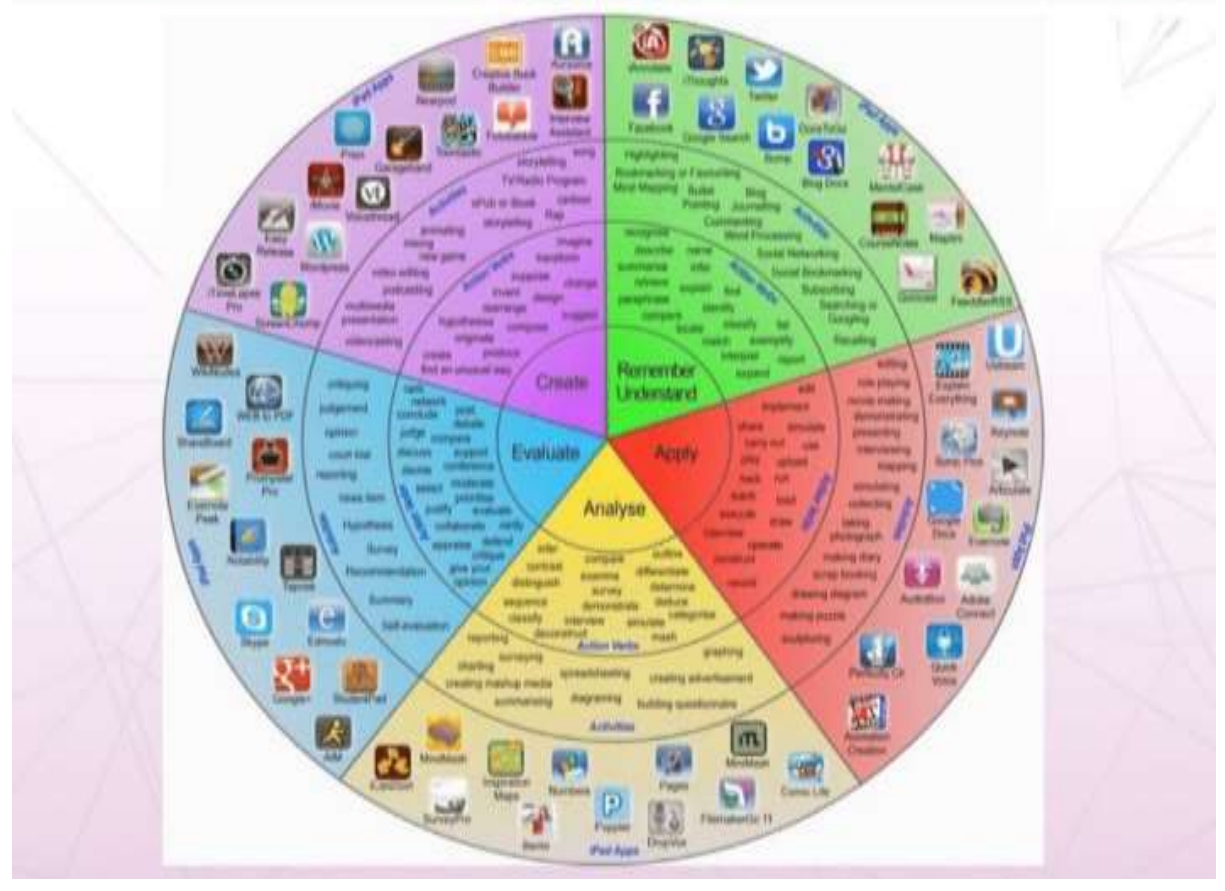

Based on Figure 3, which explains the thematic selection of media that can be used in writing skills. This provides an opportunity for teachers and students to explore ideas in written form. As the analysis of each competency can be seen through the following classifications.

\section{Remembering and Understanding}

Writing lessons for beginners can use Facebook and Google search. As remembering competence is still the basic competence of students' writing skills. This can be combined with social media users as native speakers. Native speakers function to provide essential written communication on Facebook for each student. 
As the theme that is still relevant is introductions. Introductions can be a topic of discussion in writing works. Even though the written sentence is still in the form of a simple sentence, it can be used contextually for each student. When students have produced writing language via Facebook, this can be reported on their learning progress contextually (Al-Kabi et al., 2018).

Through the Facebook friendship media, students can remember introductory sentences or other relevant topics. As explained, contextual-based learning can provide students with experiences and opportunities to apply or understand more deeply (Febriani et al., 2020). This is because they disclose in writing according to their respective conditions and circumstances.

Learning writing skills identifies students' understanding to understand the text then rewritten in paragraph form. On that basis, lecturers can use the google document application as a medium for writing to reach student understanding. This can be supported by the use of simple sentences in expressing students' ideas. For example, they are using the Mubtada Khabar sentence design, commonly referred to as the number of a nominal sentence.

Like other media, students can promote their writing in the form of a promotional invitation (merchandise). This aims to increase understanding in the context of persuasion. Based on the topic being discussed. It's just that the teacher can determine the stages of experience and can use the Google document or WhatsApp media intensely.

As the sentence is written in the form of a compelling invitation. Or, if you want a different topic and discussion, the instructions given to students can vary. As the process of determining this media is adjusted to students' basic understanding in understanding the grammar of writing Arabic.

\section{Applying and Analyzing}

The process of learning to write based on MOTS can be in the form of students' ability to apply and analyze a simple sentence. This is still in the application process, and knowing the punishment with media online. The teacher's instructions can use the media intermediary Edmodo, Skype, Youtube, Google search, etc. This can allow students to explore the written materials that come from these media. As related to the content or presentation of writing Arabic.

At the application and analysis stage, students are expected to give arguments and opinions about wrong sentences by justifying or providing suggestions on their friend's writings in a context. When the second indicator has been achieved, the standard writing stage can be increased based on HOTS using other media Applications. The teacher can provide instructions for applying simple sentences to more complex sentences (Florea \& Hurjui, 2015) to aid the development of students' experiences in writing texts.

The implementation and analysis processes are critical stages before entering the HOTS category. To achieve these two categories, writing exercises are continuously provided. This is implemented in a gradual standard, from writing simple sentences to more complex modified sentences. Then students can create more systematic paragraphs on the HOTS system.

\section{Evaluate and Creating}

The lecturer and students discuss the given assignment by allowing the students to criticize their friend's work. Some examples are through comments on 
Instagram or YouTube so that lecturers can find out students' activeness in learning Arabic. Words obtained were from students and lecturers and from social media friends who helped correct mistakes in foreign languages. These are some steps that lecturers can take in teaching Arabic at UIN Maulana Malik Ibrahim Malang online. This method can be developed again following the conditions of students and adequate online facilities.

In the process of evaluating writing skills, it can be done through peer review of each student. This can be done on Instagram and other media. As the form of student skills in evaluating can be seen as follows.

\section{Figure 4.}

\section{Peer Review}

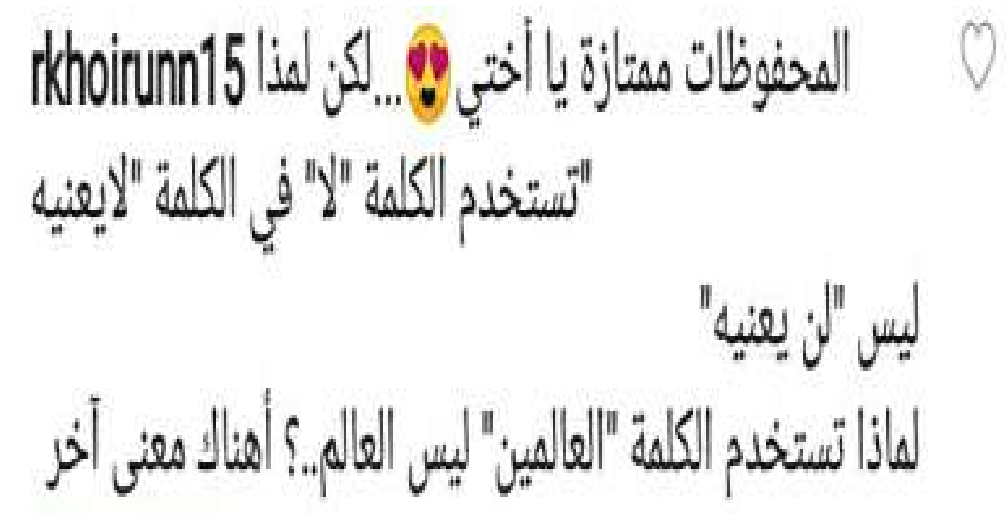

Figure 4 shows that peer review activity can take place using Instagram media in the comments column. This peer review form can allow students to express corrections to mistakes used by their friends (Liu et al., 2017).

Figure 5.

Student Creations

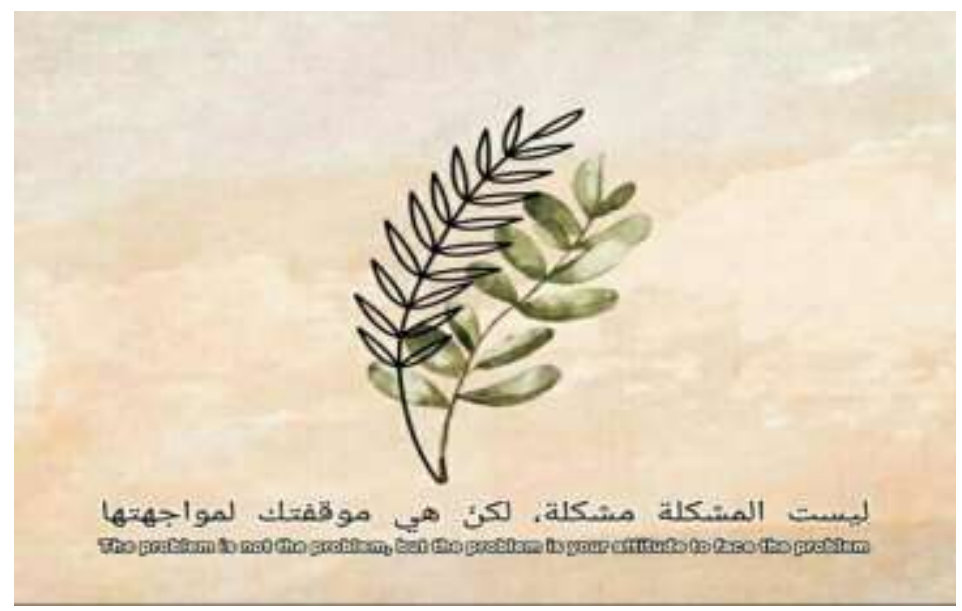

Based on Figure 5, the process of creating is the last process of bloom taxonomy. This is indicated when students can provide creativity in the form of productive skills, writing. Through student work, it is ensured that each individual produces different designs and sentences according to the learning topic (Rahman \& Manaf, 2017). 
Based on these data, the learning media can provide positive supports for developing students' critical and creative thinking skills (Kivunja, 2015). This is a primary indicator so that improving writing skills can be implemented in daily communication activities. As writing skills are a necessity for students to convey ideas.

\section{Conclusion}

Writing learning media is an essential concern in producing student work. This is a basic need related to the demands of critical and creative thinking in Arabic learning's internalization. The findings of this study indicate that Arabic learning media can be divided into five primary classifications according to the bloom taxonomy; media understanding stage; YouTube, Facebook, Google search, Twitter, media application stages: Quick Voice, Animation Creation, Google Doc, media analysis; mind mapping, nu, bars, pages, media evaluation; Edmodo, Skype, Google search, WhatsApp, creative media; WordPress, iMovie, YouTube, Creative Book, Instagram. The findings of this study indicate that using online media is one of the efforts to improve creative and critical thinking processes in improving Arabic writing skills. This research only examines the written media and Bloom's taxonomy theory. Further research is still needed to test the effectiveness of each media used during the COVID-19 situation.

\section{References}

Abidah, A., Hidaayatullaah, H. N., Simamora, R. M., Fehabutar, D., \& Mutakinati, L. (2020). The impact of Covid-19 to Indonesian education and its relation to the philosophy of "Merdeka Belajar." Studies in Philosophy of Science and Education, 1(1), 38-49. https://doi.org/10.46627/sipose.v1i1.9

Al-Kabi, M., Alsmadi, I., Khasawneh, R., \& Wahsheh, H. (2018). Evaluating social context in arabic opinion mining. International Arab Journal of Information Technology, 15(6), 974-982.

Aljojo, N., Munshi, A., Almukadi, W., Zainol, A., Alanaya, I., Albalawi, H., Alharbi, G., Almadani, N., Almohammadi, E., Kadu, A., \& Abdulghaffar, N. A. (2019). The design and implementation of an arabic pronunciation application for early childhood. Journal of Technology and Science Education, 9(2), 136-152. https://doi.org/10.3926/jotse.486

Arndt, H. L., \& Woore, R. (2018). Vocabulary learning from watching YouTube videos and reading blog posts. Language Learning and Technology.

Bahasoan, A. N., Wulan Ayuandiani, Muhammad Mukhram, \& Aswar Rahmat. (2020). Effectiveness of online learning in pandemic Covid-19. International Journal of Science, Technology \& Management, 1(2), 100-106. https://doi.org/10.46729/ijstm.v1i2.30

Chang, C. L., \& Fang, M. (2020). E-Learning and online instructions of higher education during the 2019 Novel Coronavirus diseases (COVID-19) Epidemic. Journal of Physics: Conference Series, 1574(1), 0-5. https://doi.org/10.1088/1742-6596/1574/1/012166 
Dhawan, S. (2020). Online learning: A Panacea in the time of COVID-19 crisis. Journal of Educational Technology Systems, 49(1), 5-22. https://doi.org/10.1177/0047239520934018

Febriani, S. R. (2020). Implementation of arabic learning during COVID-19 emergency in Indonesia: HOTS, MOTS, OR LOTS? Alsinatuna, 5(2), 117-129.

Febriani, S. R., Wargadinata, W., Syuhadak, S., \& Adam, F. M. (2020). Design of Arabic Learning for Senior High School in the 21 st Century.Al-Bayaan. 12(1), 1-21. https://doi.org/10.24042/albayan.v12i1.5886

Febriani, S. R., Widayanti, R., Amrullah, M. A., \& Mufidah, N. (2020). Arabic learning for elementary school during COVID-19 emergency in Indonesia. OKARA, 14(1), 67-80. https://doi.org/10.19105/ojbs.v14i1.3194

Florea, N. M., \& Hurjui, E. (2015). Critical thinking in elementary school children. Procedia - Social and Behavioral Sciences, 180(November 2014), 565-572. https://doi.org/10.1016/j.sbspro.2015.02.161

Freeman, I. M., Ed, D., \& Ave, E. A. (2016). Life Skills for 21 st Century Learners. $3(10), 49-52$.

Halverson, A. (2018). 21 st Century Skills and the " 4Cs" in the English Language Classroom by Andy Halvorsen. American English Institute, 0-4.

Hamat, A., \& Hassan, H. A. (2019). Use of social media for informal language learning by Malaysian University Students. 3L: Language, Linguistics, Literature, 25(4), 68-83. https://doi.org/10.17576/3L-2019-2504-05

Khatri, P., Singh, S., Belani, N. K., Leng, Y. Y., Lohan, R., Wei, L. Y., \& Teo, W. Z. (2020). YouTube as source of information on 2019 novel coronavirus outbreak: A cross sectional study of English and Mandarin content. Travel Medicine and Infectious Disease. https://doi.org/10.1016/j.tmaid.2020.101636

Kivunja, C. (2015). Innovative Methodologies for 21st century learning, teaching and assessment: A convenience sampling investigation into the use of social media technologies in higher education. International Journal of Higher Education, 4(2), 1-26. https://doi.org/10.5430/ijhe.v4n2p1

Liu, X., Li, L., \& Zhang, Z. (2017). Small group discussion as a key component in online assessment training for enhanced student learning in web-based peer assessment. Assessment and Evaluation in Higher Education, 2938(May), 1-16. https://doi.org/10.1080/02602938.2017.1324018

Mbodj, N. B. (2020). Online teaching : The affordances of PowerPoint and YouTube for a more inclusive approach. GATESOL in Action Journal, 30(1), 91-100.

Musa, F., Mufti, N., Latiff, R. A., \& Amin, M. M. (2012). Project-based learning (PjBL): Inculcating soft skills in 21st century workplace. Procedia - Social and Behavioral Sciences, 59(2006), 565-573. https://doi.org/10.1016/j.sbspro.2012.09.315

Nassiri, N., Lakhouaja, A., \& Cavalli-Sforza, V. (2018). Arabic readability assessment 
for foreign language learners. Lecture Notes in Computer Science (Including Subseries Lecture Notes in Artificial Intelligence and Lecture Notes in Bioinformatics), 10859 LNCS, 480-488. https://doi.org/10.1007/978-3319-91947-8_49

Pentury, H. J., \& Anggraeni, A. D. (2019). Using Bloom's Taxonomy in social media Applications. ISOFOLL, 465-475.

Rachmijati, C., Anggraeni, A., \& Apriliyanti, D. L. (2019). Implementation of blended learning through Youtube media to improve students' speaking skill. OKARA: Jurnal Bahasa Dan Sastra, 13(2), 153. https://doi.org/10.19105/ojbs.v13i2.2424

Rahayu, S. P., \& Putri, W. S. (2019). Uploading speaking assignment to YouTube channel as an effort in increasing student's pronunciation skill. EnJourMe (English Journal of Merdeka) : Culture, Language, and Teaching of English, 3(2), 35-45. https://doi.org/10.26905/enjourme.v3i2.2741

Rahman, S. A., \& Manaf, N. F. A. (2017). A Critical analysis of Bloom's Taxonomy in taching creative and critical thinking skills in Malaysia through English literature. English Language Teaching, 10(9), 245. https://doi.org/10.5539/elt.v10n9p245

Tai, T. Y., Chen, H. H. J., \& Todd, G. (2020). The impact of a virtual reality app on adolescent EFL learners' vocabulary learning. Computer Assisted Language Learning, O(0), 1-26. https://doi.org/10.1080/09588221.2020.1752735

Teimourtash, M., \& YazdaniMoghaddam, M. (2017). On the plausibility of Bloom's higher order thinking strategies on learner autonomy: The Paradigm Shift. Asian-Pacific Journal of Second and Foreign Language Education, 2(1). https://doi.org/10.1186/s40862-017-0037-8

Wargadinata, W., Maimunah, I., Febriani, S. R., \& Humaira, L. (2020). Mediated arabic language learning for Arabic students of higher education in COVID19 situation. Izdihar: Journal of Arabic Language Teaching, Linguistics, and Literature, 3(1), 59-78. https://doi.org/10.22219/jiz.v3i1.11862

Xuan, Z. (2017). Innovation in language learning and teaching. Innovation in Language Learning and Teaching, Icc, 261-287. https://doi.org/10.1057/978-1-137-60092-9

Yin, R. K. (2003). Robert K. Yin Case Study Research Design and Methods, Third Edition, Applied Social Research Methods Series, Vol 5 2002.pdf (pp. 1-181).

Zamzami Zainuddin. (2017). First-Year college students' experiences in the EFL flipped classroom: A case study in Indonesia. International Journal of Instruction, 10(1), 133-150. http://www.e-iji.net/dosyalar/iji_2017_1_9.pdf

\section{Copyright Notice}

Authors retain copyright and grant the journal right of first publication with the work simultaneously licensed under a Creative Commons Attribution 4.0 
International License that allows others to share the work with an acknowledgement of the work's authorship and initial publication in this journal.

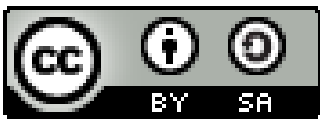


THIS PAGE INTENTIONALLY LEFT BLANK

Jurnal Ilmiah Program Studi Pendidikan Bahasa Arab IAIN Palangka Raya Vol. 9, No. 1/1-12 Al-Ta'rib | p-ISSN 2354-5887 | e-ISSN 2655-5867 